\title{
Sport as a Vehicle for Health Promotion: A Shared Value Example of Social Programming
}

\begin{abstract}
Professional sport organizations are increasingly encouraging physical and mental wellness by developing and deploying health promotion activities via socially responsible programming and messaging. However, delivery, deployment, and scope issues, all of which limit observable and sustainable impacts on health promotion and behavior, encumber many socially responsible programs. The authors frame the study using a shared value perspective to demonstrate that sport managers can effectively promote health when the professional sport organization is concurrently attempting to deliver social and business value. To illustrate this approach, the authors used a health-related intervention program funded and delivered by a professional sport league as the research context. The authors undertook a mixed-method, quasi-experimental study to determine the potential to achieve social value (e.g., physical health and mental wellness) and business value (e.g., team, league, and sport affinity, and patronage). The results show that the business-centric effects were stronger among a group of youth beneficiaries than they were among some health- and wellnesscentric variables. The authors discuss the significant effects through a shared value lens and posit several areas for future research.
\end{abstract}

Keywords: Corporate Social responsibility, Physical Health, Mental Wellness, Shared Value. 


\section{Introduction}

Using sport to promote health is not a new phenomenon. For decades, scholars and policy-makers have touted the benefits of sport participation ranging from the salubrious to the cathartic to the physiological (Khan et al., 2012; Micheli et al., 2011). More recently, however, sport teams, leagues, and other sport-related organizations have begun to encourage both individual and societal well-being by formally developing and deploying health promotion activities and messages via corporate social responsibility programming. Nearly a decade ago, sport scholars (Babiak \& Wolfe, 2009; Godfrey, 2009; Walker \& Kent, 2009; Walters, 2009) identified health-related activities as one of the primary means of socially responsible deployment in professional sport. This trend has shown no signs of abating, as health promotion programs are commonly used social platforms among professional sport organizations (Inoue, Kent, \& Lee, 2011).

Brady, Perry, Murdoch, and McKay (2010), Gray et al. (2013), Robertson et al. (2013), and Irwin et al. (2010) all contended the attractiveness and visibility of professional sport (i.e., 'the hook') helps recruit social program participants in an attempt to yield positive health behaviors on the intended beneficiaries and their communities. However, many social programs are delivered in the short-run, often underfunded, structurally fragmented, and have limited participant capacities, all of which encumber consistent, positive, and observable impacts (Inoue et al., 2015; Walker \& Hills, 2017). Consequently, the net influence of social responsibility on measurable health-related outcomes is limited, which makes scaling and replication difficult. Similarly, scholar know little about how sport organization involvement (i.e., the process) catalyzes or inhibits the intended effects on participants and communities. Given the litany of factors that impact health behavior, ranging from intrapersonal to institutional to environmental, and the complex reciprocal relationships of these factors (Baranowski, Perry, \& Parcel, 2002; Godin \& Kok, 1996; Johansen et al., 2006), it is not 
surprising that sport-sponsored (and delivered) social responsibility programs may fall short of an impactful health promotion experience. It is important to note, however, there is a limited (albeit expanding) body of recent research detailing the outcomes of health promotion programs in sport (see Brady et al., 2010; Gray et al., 2013; Inoue et al., 2015; Irwin et al., 2010; Pringle et al., 2013; Rowe, Karg, \& Sherry, 2018).

According to Kramer and Porter (2011), social responsibility initiatives are often reactions to external pressures that have “... emerged largely to improve firms' reputations and are treated as a necessary expense" (p. 65). As a negative outcome of this approach, Walker, Hills, and Heere (2017) demonstrated that when consumers perceived a sport organization as deploying social responsibility opportunistically (i.e., seeking paybacks rather than social impact), negative perceptions result. Others have also noted that certain forms of social responsibility can run the risk of consumer scepticism if the motives are perceived as inauthentic (see Du, Bhattacharya, \& Sen, 2010; Ellen, Webb, \& Mohr, 2006; McWilliams \& Siegel, 2011; Siegel \& Vitaliano, 2007). Such negative perceptions are also produced when social responsibility programs are not well-aligned with an organizations core business objectives (McElhaney, 2007). Accordingly, many organizations have supported programs intended to strike a more transparent balance of both normative (i.e., social) and instrumental (i.e., business) benefits. For sport organizations, this means that social responsibility should deviation from low-fit to high-fit programs with personal, developmental, and societal underpinnings (e.g., health-, education-, and community-related). As a result, many social responsibility/wellness programs now exist in sport: the National Basketball Association (NBA) and the Women's National Basketball Association (WNBA) support NBA/WNBA FIT; the Memphis Grizzlies support a Get Fit with the Grizzlies program; the National Football League (NFL) has promoted Play 60 in the United States since 2007, which has since expanded to the United Kingdom (UK); the United States Center for Disease 
Comparison supports Tobacco Free Sports, mirrored in the UK by 'SomkeFree Sports'; Nike promotes both Designed to Move and Made to Move physical activity agendas; and the London 2012 Olympic Games promised to Inspire a Generation to be physically active. According to the Ottawa Charter for Health Promotion (WHO, 1986), health advancement requires three foundational tenets: (a) advocating for favourable conditions, (b) enabling through supportive structural conditions, and (c) mediation by entities situated outside of the health sector. While the aforementioned programs are seemingly operating under this general framework, clear and marked health- and wellness-related outcome data are not publically available for these programs.

Limited outcome data may be a by-product of unsuccessfully linking social programming to core business interests, which, according to Kramer and Porter (2011), hinders program sustainability and positive and lasting social and business benefits. Given the suggestion of McElhaney (2007) regarding the need for alignment between business health and social health, we suggest a more sustainable model for sport organizations is the pursuit of shared value (Kramer \& Porter, 2011), which emphasizes creating social and business value synergistically. This idea deviates from the traditional goals of social responsibility, which have tended to prioritize economic value creation over social value creation (Hart, 2005; Pavlovich \& Corner, 2014). A large portion of the social responsibility work performed in sport characterizes this point. For example, work published in this space has discussed how social responsibility enables numerous business-centric perspectives such as corporate investments (Kim, Kwak, \& Kim, 2010), reputation-building (Walker \& Kent, 2009; 2013), corporate credibility (Inoue \& Kent, 2012), marketing outcomes (Irwin, Lachowetz, \& Clark, 2010), stakeholder satisfaction (Walters \& Tacon, 2010), cost savings (Walker \& Mercado, 2016), and financial performance (Inoue, Kent, \& Lee, 2011). 
In contrast, the shared value perspective implies that not all business profits are equal, whereby profits gained from a social purpose represent a higher form of capitalism, especially when the social agenda aligns with the core function of the business (Driver, 2012). Porter and others have maintained that a shared value position addresses social and community needs, and enables organizations to design value chains that can produce economic value because of their social investments (Beschorner, 2014; Porter \& Kramer, 2011). Moreover, addressing social problems related to a company's core business provides the "most fertile opportunities" (p. 75) for creating shared value (Porter \& Kramer, 2011). And the well-established links between sport, physical activity, and health outcomes (Bailey et al., 2013) means that professional sport organizations are well-suited to develop and deploy health promotion initiatives, since they have the ability to leverage their market presence to achieve social impact (Inoue et al., 2015). Sport entities can enable favourable conditions and collaborate with a number of external stakeholders to promote social health programs (WHO, 1986). Health promotion through sport can also enable business value for professional sport organizations on several levels. First, an intervention that achieves health outcomes through sport will likely yield residual affinity for the sport. Second, when program beneficiaries engage directly with a high-profile organization, increased organizational connectivity should result. Third, since organizational competitiveness and the health of the communities around it are closely connected (Kramer \& Porter, 2011), a healthy and successful community creates product demand, a valuable public asset, and a supportive environment for other social outcomes to materialize.

\subsection{Study purpose}

Through this shared value lens, and in light of the pressing need for business/society alignments, we present a heuristic example of a collaborative venture between a sport business and several UK schools, and the resulting beneficiary outcomes, community/societal 
benefits, and strategic organizational paybacks. Specifically, we examined a sport-based social program, delivered by a professional sport league (i.e., 'The League') in a foreign market (i.e., London, United Kingdom) that sought to increase physical activity levels and promote mental wellness through the 'hook' of sport. On the business side of the operational discussion, The League sought to leverage program participation as a means to increase affinity for The League, teams, and sport itself. Structurally, one of six League-affiliated teams collaborated with one participating school (i.e., one team per school) in greater London to engage with program participants via different means. Based on these program characteristics, we developed the following research questions to guide this investigation:

Research Question 1a: What effect did the program have on levels of physical activity, physical activity enjoyment, and physical activity commitment?

Research Question 1b: What aspects of the program enabled the effect on levels of physical activity, physical activity enjoyment, and physical activity commitment? Research Question 2a: What effect did the program have on mental wellness, including respect, teamwork, integrity, and perseverance?

Research Question 2b: What aspects of the program enabled the effect on mental wellness, including respect, teamwork, integrity, and perseverance?

Research Question 3a: What effect did the program have on participant affinity, including identification, advocacy, and patronage, with the professional league, teams, and sport?

Research Question 3b: What aspects of the program enabled participant affinity, including identification, advocacy, and patronage, with the professional league, teams, and sport? 


\section{Social and business value}

\subsection{Physical inactivity}

Physical inactivity represents a significant threat to the health of London's youth. Recent data show that only $24 \%$ of boys and $22 \%$ of girls in London meet the recommended level of one-hour of physical activity per day (British Heart Foundation, 2015). In the broader UK, physical activity levels have dropped by $20 \%$ from 1961 to 2005, and experts project the figures to drop an additional 15\% by 2030 (Ng \& Popkin, 2012). Considering the documented link between physical activity and health benefits (Bailey et al., 2013), it is not surprising to note that approximately one in three children in UK are overweight or obese (King's College London, 2015). Lack of physical activity among youth has both immediate and long-term impacts, given that inactive children are likely to become inactive adults (MacArthur et al., 2012), which can lead to health problems (Stevenson, 2010).

\subsection{Mental wellness education}

Health and wellness promotion professionals have intentionally designed programs to focus on both mental and physical health by targeting behavioral, psychological, and social factors (Peterson, 2006). In fact, researchers have indicated that mental and physical health are reciprocally related, with changes in one often leading to changes in the other (Miller, Gilman, \& Martens, 2008). Some have criticized the UK Government for “... taking the joy out of childhood by overemphasizing exam preparation" (Paton, 2013, para. 3), and limiting social and developmental programs. This criticism catalyzed the need to "... place character building at the heart of the curriculum alongside traditional academic study," which can contribute to happier and more confident pupils (Paton, 2013, para. 3). As one example, a social-emotional and character development program (i.e., Positive Action) positively influenced school-level achievement, attendance, and disciplinary outcomes in the UK (Snyder et al., 2009). Furthermore, character strengths correlate positively with overall 
wellness among adolescent populations (Gillham et al., 2011). Understanding the need for character education, The League embedded several core values into the program curriculum to promote mental wellness among the program participants.

\subsection{League, team, and sport affinity}

The League in this case is attempting to penetrate an already saturated sport marketplace in London with a new sport offering. Moreover, in order to translate The League's sport in this market, The League must establish a fan base where one does not exist. By focusing on youth, The League can grow a fan base who, if they become fans, will engage with The League and its member teams (hopefully) over their lifetime. This bottom-up approach deviates from established models for sport and team identification whereby the need for affiliation, social well-being, the impact of socialization agents, team and league success, and similarity with players have been confirmed as salient antecedent conditions to sport and team fandom (Heere \& James, 2007). The approach used by The League was an attempt to provide social value by leveraging the novelty of a new sport offering with participation in that sport as a means of socialization and competition.

\section{Program description and activities}

While developed and funded by The League, the school-based program in greater London (UK) was delivered by a third party with experience with instructional design. The League specifically selected two London boroughs (i.e., Brent and Lambeth), both of which ranked low in health indicators, as defined by the Trust for London and New Policy Institute (2013). Delivered during school hours within time scheduled for compulsory Physical Education (PE) lessons, the program lasted for one hour a week over a 12-week period. Six schools (i.e., three in each borough) participated. Each participating school had a supporting member team from The League who engaged with the school and its pupils through teamrelated branding. Engagement across the program included actions such as providing apparel, 
merchandise, former player visits to schools, video calls from team mascots, and player coaches who provided character lectures throughout the 12 weeks. The program culminated in a tournament between schools, with a current player of the partnering team serving as the coach.

The program had three interrelated elements: (a) physical activity, (b) mental wellness, and (c) league, team, and sport affinity and associated outcomes such as patronage intentions. The third party deliverer made use of accredited coaches with experience of delivering The League's sport, and participating students ranged from 9-11 years old for both the treatment and the comparison groups. Recruited from the same schools as the participants, the comparison groups helped strengthen the causal inferences. For example, if other activities (e.g., the second hour of PE lessons) were causing the change and not the treatment, this will be picked up in the between group comparisons of the treatment and comparison groups if both groups experience a statistically significant change.

\subsection{Physical activity}

People develop at a young age the fundamental motor skills that serve as building blocks for physical activity; and preferences and motivations for various forms of physical activity form as children head into adolescence (Okely, Booth, \& Patterson, 2001). Thus, the deliverer and The League believed delivering the program in primary schools would have the greatest impact. Sessions were designed to develop central, fundamental movement skills (e.g., running, balance, jumping, throwing, kicking, and catching), which children must master at a young age to become physically literate. The literacy movements provided participants with a foundation from which the physical activity associated with the sport could be enjoyed (Okely et al., 2001; Whitehead, 2013). Coaches developed age appropriate drills and participants chose their activities to add a layer of volition to the core activities. 
Beyond developing fundamental and enjoyable movements, the programmers sought to provide an inclusive and inspiring environment so physical activity could naturally manifest. The League's sport represented an alternative to the UK's mainstream sports that failed to engage sufficiently London's youth in appropriate levels of physical activity. For example, less than a quarter of UK youth meet the Chief Medical Officer's guideline of 1hour of physical activity per day (National Statistics, 2017). The sport provided a new endeavor in London where participants could become part of something novel, exciting, and fun, and develop a unique physical activity identity to serve as a source of motivation for physical activity (Epstein, 1998; Green, 2004; Hughson, Inglis, \& Free, 2005). As a sport new to the UK market, inequalities in skills are yet to develop; thus, all participants began the program on an equal level, removing a potential barrier of a lack of confidence to participate in the sport. In order to provide universal access, all sessions and competitions integrated an equal balance of boys and girls. Attaching physical activity to The League's brand provided participants with direct access to role models (e.g., former and current players) for maintaining physical activity. Although players were from a novel sport, the program made use of video clips to establish the players as professional, talented athletes for added credibility and context. While the physical activity element of the program only engaged participants for one hour per week, homework of practicing skills and drills reinforced the lessons and engender habitual physical activity outside of traditional school-based PE classes.

\subsection{Mental wellness}

The League sought to enhance the mental wellness of participants by delivering a character-based curriculum via traditional in-class experiences. Accordingly, The League conducted focus groups with former players that discussed the values that most embodied The League. We employed thematic analysis to establish a list of wellness attributes that were embedded in the program curriculum: (a) respect, (b) teamwork, (c) integrity, and (d) 
perseverance. Over the 12-week period, participants were introduced to the curriculum methodology of learning, doing, and becoming in order to understand the framework by which the mental wellness attributes would be delivered. Covered over three non-consecutive weeks, sport terminology and analogies helped educate participants via the following methods: defining of concepts, activities, object lessons, physical challenges, scenarios, and stories. Each week was segmented into three independent modules: (a) learning (i.e., an introduction of important information and ideas about each attribute); (b) doing (i.e., exploration of how each participant should apply the attributes through activities, situations, and on-field challenges); and (c) becoming (i.e., participants were encouraged to envision themselves as a person who lived the specific attribute before setting a goal for adopting said attribute). Former players served as role models, with a different player allocated as the role model for each attribute. Current players also served as role models whereby learning of the attributes occurred through imitation and observation.

\subsection{League, team, and sport affinity}

The intervention required participants to play The League's sport, thus providing opportunities for participants to develop an affinity with the sport. To activate team affinity, each school partnered with one of six league-affiliated teams. Team engagement and the endof-program tournament between the six participating schools reinforced The League as the primary touch-point for participants. The League sought to activate affinity by the use of League videos to illustrate the sport-specific skills taught in the physical activity component. League players helped illustrate the wellness attributes taught as part of the mental wellness curriculum. 


\section{Method}

\subsection{Procedure}

Data collection consisted of pre- (i.e., 1-week before) and post-program (i.e., 1-week after the program) questionnaires, physical activity tracking logs, participant focus groups, and administrator interviews. A sequential mixed-methods design was utilized, which entailed "... collecting and analyzing quantitative and then qualitative data in two consecutive phases within one study" (Ivankova, Cresswell, \& Stick, 2006, p. 3). In addition, the researches employed a dominant status sequential approach (Johnson \& Onwuegbuzie, 2004), whereby pre- and post-intervention quantitative data were collected. Combining both quantitative and qualitative data enabled the research team to take advantage of the complementary strengths of each data type to answer the posited research questions, a guiding principle of mixed-method research (Johnson \& Turner, 2003). Quantitative data measured the size of the significant effects so the results could be extrapolated to the population (Firestone, 1993). Qualitative data captured the complexity of the processes behind effects, and to capture the meanings stakeholders brought to the program (Creswell, 2012; Denzin \& Lincoln, 2011).

\subsection{Quantitative technique}

We designed a quasi-experiment whereby participants were asked to complete questionnaire related to physical activity, mental wellness, and sport, team, and league affinity, and patronage before and after the program (Cordray, 1986). This design allowed for comparisons between pre- and post-treatment measurements, as well as between experimental and comparison groups for all research variables. This method assisted us with establishing causal links between the intervention and outcomes (Hakim, 2000). Construction of formal, randomized control groups for the project was not feasible because the program was delivered in schools to whole classes from which it was not possible to separate into 
different conditions. Nor was it possible to collect data at non-participating schools due to permission and access issues. However, to minimize selection bias, we identified comparison groups from participating schools that had multiple classes in each year and where the nonparticipating classes would participate in a later rendition of the program. This delivery method provided a non-random comparison group effectively on a waiting list for the intervention, which according to Sefton et al. (2002), is a valid means of comparison group construction when true random assignment is not possible. In total, 12 classes formed the experimental group and four classes formed the comparison group. Since the comparison group was from the participating schools, these classes mirrored the demographic characteristics of the treatment group. However, this approach meant there was risk of comparison group contamination whereby presence of the intervention cascaded beyond the participating classes. It was not possible to match a control group class with each treatment group class because some of the schools had only one class per year. Only schools with multiple classes per year provided a control group class.

We analysed the questionnaire data using descriptive statistics, repeated measures analysis of variance (ANOVA), and paired-sample $t$-tests to detect changes among the research variables from pre to post-intervention, and between the experimental and comparison groups. In addition to the main statistical effects, effect sizes for the significant results were used to determine the level of practical significance. According to Cohen (1992), $d=0.2$ is a small effect, $d=0.5$ is a moderate effect, and $d=0.8$ is a large effect.

\subsection{Quantitative measures}

\subsubsection{Physical activity and physical inactivity}

Levels of physical activity were operationalized in two manners: (a) intentional engagement in physical activity, and (b) intentional engagement in sedentary behavior (i.e., screen time). Whereas engagement in physical activity is a well-established preventive 
behaviour, there is considerable evidence suggesting sitting time, typically due to screen time for youth and adolescents, is a deleterious health hazard (Owen et al., 2010a). Moreover, even when meeting physical activity guidelines, prolonged sitting can have independent compromising health outcomes (Hamilton et al., 2008; Owen et al., 2010b).

To assess engagement in physical activity, we adopted a last seven days recall period similar to the Physical Activity Questionnaire for Children (Kowalkski, Crocker, \& Donen, 2004) and Youth Physical Activity Questionnaire (YPAQ; Corder et al., 2008). Both instruments are valid and reliable self-reporting means of tracking physical activity (Corder et al., 2008; McCrorie, Perez, \& Ellaway, 2017). Following YPAQ procedures, respondents were asked to recall for the previous seven days how many days, and on average, for how many minutes per day they had engaged in physical activities that: (a) caused them to be out of breath (i.e., vigorous intensity PA), (b) caused their breathing to be fast (i.e., moderate intensity PA), and (c) did not impact their breathing (i.e., low intensity PA). Impact to breathing (i.e., breathlessness) served as an anchor point for responses for several reasons. First, perceived exertion (i.e., how one subjectively feels while exercising) corresponds well to physiological biomarkers during exercise (Noble et al., 1983). Moreover, reviews outlining the limitations of physical activity questions have recommended ascribing biological meaning to the often used terms of light, moderate, and/or vigorous physical activity (Shephard, 2003). Second, breathlessness is a memorable, easy to identify, and an understandable cue that corresponds to various activity levels (Mayo Clinic, 2017). Finally, time spent physically active without breathing impact. This variable addresses criticisms of many physical activity measures that fail to capture the lower end of the physical activity continuum, since sedentary behavior is often overlooked (Tudor-Locke \& Myers, 2001).

To assess physical inactivity (i.e., sedentary behavior), we used screen time as a proxy measure given prolonged TV viewing and total screen time in adolescence are linked to 
worse cardiovascular health indicators later in life (Grøntved et al., 2014). Again, mirroring practices of YPAC, participants recalled for the previous seven days how many days, and, on average, for how many minutes per day they had: (a) watched or streamed television, (b) surfed the internet or communicated on social media, and (c) played computer games. These measures are easy to estimate for the participant (e.g., two shows watched $=60$ minutes) and more memorable to the participants. For example, walking to a friend's house is more likely to go unrecognized as being active, while playing a video game with a friend more easily resonates. Other investigations seeking to measure sedentary behaviors of youth have similarly assessed watching TV, playing video games, phone use, and other non-homework related computer use, such as time spent on social media (see Cui et al., 2015). Physical activity enjoyment (i.e., the extent to which participants enjoy physical activity) was measured via an adapted version of Moore et al.'s (2009) Physical Activity Enjoyment Scale (4 items, $\alpha=.81$ ). We measured physical activity commitment (i.e., the extent to which participants are committed to physical activity) with an adapted version of Scanlan et al.'s (1993) sport commitment scale (5 items, $\alpha=.74$ ).

\subsubsection{Mental wellness}

The mental wellness items matched the program curriculum, which was developed based on the four wellness/character pillars established by The League. Respectfulness (3 items, $\alpha=.81$; from Van Quaquebeke \& Eckloff, 2010); teamwork (4 items, $\alpha=.70$; from Park \& Peterson, 2006); integrity (4 items, $\alpha=.71$; from Park \& Peterson, 2006); and perseverance (4 items, $\alpha=.70$; from Duckworth et al., 2007). All mental wellness questionnaire items were adapted for age-appropriateness and were pilot tested with 9-11 years olds in the US and UK prior to the evaluation taking place. 


\subsubsection{League, team, and sport affinity}

A slightly modified version of the team identification scale by Dimmock and Grove (2006) measured business value with regards to affinity for The League's teams participating in the program (3 items, $\alpha=.76$ ), affinity with the The League itself (3-items, $\alpha=.82$ ), and affinity with the professional sport (3 items, $\alpha=.83$ ). As James (2001) noted, team-related preferences begin to form between ages 5-9. Consequently, the affinity measures were appropriate for this age group to help understand if the socializing agent of The League, and sport-based intervention, cognitively influenced League, team, and sport affinity for the sample. All affinity items were adapted for age-appropriateness and were pilot tested with 911 years olds in the US and UK prior to the evaluation taking place.

\subsubsection{Advocacy and patronage}

Items were used to measure team advocacy ( 3 items, $\alpha=.75$ ), team patronage ( 3 items, $\alpha=.89$ ), league advocacy ( 3 items, $\alpha=.81$ ), league patronage ( 3 items, $\alpha=.88$ ) from Walker and Kent (2009). Similar to the affinity constructs, James (2001) pointed out that socializing agents were also influential for certain behavioral intentions to manifest early in one's life (e.g., merchandise consumption, reading, viewership, and event attendance). All advocacy, patronage, and participation items were adapted for age-appropriateness and were pilot tested with 9-11 years olds in the US and UK prior to the evaluation taking place.

[Insert Table 1 here]

\subsection{Qualitative technique}

We conducted twelve focus groups (two per school, one per school year, with schools each having two participating classes from years four, five, or six). There were four boys and four girls selected for each focus group, which were conducted in a separate classroom in the presence of a teaching assistant, which falls in the middle the range of six to ten participants recommended by Morgan (1996). In order to add understanding to the causal relationship of 
the effect of the program on the participants, initial questions focused on effect (e.g., What changes have you noticed in yourself since participating in the program?) before probing questions sought to establish the mechanisms behind effects (e.g., What do you think has caused this change in you?). Next, questions delved more into the specific beneficiary impacts (e.g., Tell me about your after school and weekend activities; have these changed in any way since participating in the program?), which followed with probing questions for cases where change was reported (e.g., Why are you now more physically active than you were before?). Subsequent questions delved into general fandom preferences to provide an opportunity to discuss sport, League, and team affinity (e.g., What are your favorite sports; has this always been one of your favorite sports?), which followed with additional probing questions (e.g., Why do you support [team]?). These open questions sought to establish general preferences, without biasing responses towards The League, and establishing the mechanisms behind fandom preferences. Finally, we asked general questions about delivery (e.g., What was your general experience of the program; What parts of the program benefited you most?).

In addition to the focus groups, we conducted single interviews, lasting approximately 30 minutes each, with the program designer, the head of delivery, the program coordinator, and a program coach. These data provided triangulation from the focus group data to gain additional insights into program delivery in the school setting. Analogous to the focus groups, the interviews commenced with open questions about effect (e.g., Where has the program had the greatest impact?) followed with probing questions (e.g., What was the sequence of steps that you took participants through in order to achieve these impacts?). Finally, we posed evaluative questions about delivery (e.g., What challenges did the program face; What opportunities exist the program could take advantage of?) to help The League refine their delivery protocols in the future. 
We transcribed and analysed the focus groups and interview data using an inductive coding strategy. Through this process, we extracted themes and quotes related to the delivery of the program, focusing on the processes behind the desired effects and the context of the program. We individually analyzed the transcriptions to reduce researcher bias (Maxwell, 2012) using a line-by-line open coding procedure to “... expose the thoughts, ideas, and meanings contained therein" (Strauss \& Corbin, 1998, p. 102). Segments of relevant and meaningful text codes were attributed (Spiggle, 1994) followed by axial coding to group these segments of text into larger abstract categories, to sort, synthesize, organize, and reassemble the data (Creswell \& Miller, 2000). We read each other's memos and discussed their insights, comparing coding and categories before reaching consensus on the themes and representative quotes.

\section{Results}

\subsection{Quantitative results}

A total of 272 individuals completed the pre- and post-program questionnaires $(n=$ 223 participants in the program; $n=49$ individuals in the comparison group). Ages ranged from 8-11 years $(M=9.33, S D=.56)$. Ethnicity of the sample groups was diverse (Treatment: White, 43\%, Mixed, 13\%, Asian, 12\%, Black, 25\%, other, 7\%; Comparison: White, 37\%, Mixed, 20\%, Asian, 10\%, Black, 27\%, other, 6\%;) as was the gender of the sample groups (Treatment: Boy, 56\%, Girl, 44\%; Comparison: Boy, 57\%, Girl, 43\%). Participant year in school was well distributed $(n=104$ in year $4 ; n=136$ in year $5 ; n=28$ in year 6), and the distribution of participants across the twelve participating schools ranged from 19 to 28. Preliminary data checks confirmed no violations of normality or linearity as the skewness values did not exceed \pm 2 and none of the kurtosis values exceeded \pm 7 for the research variables (Curran, West, \& Finch, 1996). Following the preliminary data checks, correlations, mean scores, and internal consistency calculations for the research variables for 
both conditions were calculated. All of the correlations and scale diagnostic values fell in the acceptable range for subsequent testing.

\section{[Insert Table 2 here]}

\subsubsection{Repeated measures ANOVA}

We conducted a series of repeated measures ANOVA analyses to compare the effects of the program on physical activity, mental wellness, and marketing-related outcomes. The between-group variables included the treatment vs. comparison (condition) samples, while the within-group variables include the pre- vs. post-program (time). We conceptually grouped the analyses according to the research questions (i.e., physical activity, mental wellness, and marketing-related effects), and report all effects in Table 3.

\section{[Insert Table 3 here]}

For Research Question 1a, we examined if engagement in the program influenced several physical activity variables (e.g., physical activity intensity, sedentary time, physical activity enjoyment, and physical activity commitment). We found a significant and positive condition $\times$ time interaction for minutes engaged in moderate $(F(5)=5.54, p=.02, d=.25)$ and vigorous intensity physical activity $(F(5)=5.54, p=.01, d=.24)$, but not for low intensity physical activity $(F(5)=.682, p=.43)$. For moderate intensity physical activity, treatment group participants reported a near three-fold increase in from time $1(\mathrm{M}=357.19$, $S D=480.02)$ to time $2(\mathrm{M}=904.15, S D=2809.76)$. For the comparison group, the effects on moderate physical activity were negative (time $1: \mathrm{M}=281.35, S D=686.88$; time $2: \mathrm{M}=$ $106.50, S D=186.30$ ). For vigorous intensity physical activity, treatment group participants reported a three-fold increase from time $1(\mathrm{M}=501.04, S D=616.50)$ to time $2(\mathrm{M}=$ $1513.54, S D=540.18$ ). For the comparison group, the effects on vigorous physical activity were positive but less pronounced (time $1: \mathrm{M}=342.87, S D=721.40$; time $2: \mathrm{M}=837.80, S D$ $=4325.21)$. 
The condition $\times$ time interaction for sedentary time was not sigmificant $(F(1)=.946$, $p=.33$ ). For sedentary time in minutes (i.e., aggregate of TV, Internet, and computing), treatment group participants reported a two-fold increase in from time $1(\mathrm{M}=619.05, S D=$ 469.60) to time $2(\mathrm{M}=1231.64, S D=3149.62)$. The comparison group, however, reported a decrease in aggregate sedentary time (time $1: \mathrm{M}=871.75, S D=775.57$; time $2: \mathrm{M}=494.42$, $S D=788.40$ ). Finally, we found a significant and positive condition $\times$ time interaction for physical activity enjoyment $(F(1)=7.89, p<.01, d=.80)$ and physical activity commitment $(F(1)=4.78, p<.03, d=.30)$. For physical activity enjoyment, treatment group participants reported a $20 \%$ increase in self-reported mean score from time $1(\mathrm{M}=3.77, S D=1.05)$ to time $2(\mathrm{M}=4.49, S D=.631)$. The comparison group, however, reported a 5\% decrease in the self-reported means score for physical activity enjoyment (time 1: $\mathrm{M}=4.57, S D=.595$; time $2: \mathrm{M}=4.31, S D=.650$ ). For physical activity commitment, treatment group participants reported an $8 \%$ increase in self-reported mean score from time $1(\mathrm{M}=3.84, S D=1.01)$ to time $2(\mathrm{M}=4.13, S D=.878)$. The comparison group reported a smaller increase in the selfreported means score for physical activity commitment (time $1: \mathrm{M}=4.57, S D=.595$; time 2: $\mathrm{M}=4.31, S D=.650)$.

For Research Question 2a, we examined if engagement in the program influenced several mental wellness variables. The condition $\times$ time interaction for the aggregated mental construct (i.e., respect, teamwork, integrity, and perseverance) was not significant $(F(1)=$ $1.20, p=.27)$. The mean score changes for these factors can be seen in Table 2 .

Finally, for Research Question 4a, we examined if engagement in the program influenced the several marketing-related variables (e.g., identification, advocacy, patronage intentions, and sport participation intentions). We found significant and positive condition $\times$ time interaction for team identification $(F(5)=3.96, p<.01, d=.85)$, sport identification $(F$ $(5)=4.01, p<.00, d=.99)$, and League identification $(F(5)=3.86, p<.00, d=.78)$. For 
team identification, treatment group participants reported an $30 \%$ increase in self-reported mean score from time $1(\mathrm{M}=3.43, S D=1.59)$ to time $2(\mathrm{M}=4.48, S D=.701)$. The comparison group reported a smaller increase in the self-reported means score for team identification (time $1: \mathrm{M}=3.56, S D=2.97$; time $2: \mathrm{M}=3.78, S D=.775$ ). For sport identification, treatment group participants reported an $26 \%$ increase in self-reported mean score from time $1(\mathrm{M}=3.52, S D=1.15)$ to time $2(\mathrm{M}=4.47, S D=.698)$. The comparison group reported a smaller increase in the self-reported means score for sport identification (time $1: \mathrm{M}=3.78, S D=.775 ;$ time $2: \mathrm{M}=4.00, S D=.850$ ). For league identification, treatment group participants reported an $22 \%$ increase in self-reported mean score from time $1(\mathrm{M}=3.68, S D=1.35)$ to time $2(\mathrm{M}=4.52, S D=.693)$. The comparison group reported a smaller increase in the self-reported means score for league identification (time 1: $\mathrm{M}=3.61$, $S D=.914 ;$ time $2: \mathrm{M}=3.86, S D=1.10)$.

For team and league advocacy, the condition $\times$ time interaction was not significant $(F$ $(3)=1.386, p=.24)$. The mean score changes for these factors can be seen in Table 2 . While there were several large mean score increases, all of the responses were still the scale midpoint (i.e., negative). For patronage intentions, and similar to the advocacy constructs, the condition $\times$ time interaction was not significant $(F(1)=.101, p=.75)$. The mean score changes for these factors can be seen in Table 2. While there were several large mean score increases between study conditions, all of the responses were below the scale mid-point (i.e., negative).

\subsection{Qualitative findings}

\subsubsection{Theme \#1 (physical activity): enjoyment and fundamentals}

The theory of physical literacy suggests that enjoyment of physical activity progresses from the development of fundamental movements (Whitehead, 2013). The program coaching isolated fundamental movements in order to enhance the enjoyment of sport and physical 
activity. According to a program coach: "we were able to break down the physical actions in [sport] to their most basic components, so that the children were able to develop them, not just for [sport], but for all sports and physical activities.” Similarly, the program designer stated: "we designed the program to focus on the basic skills of [sport]. One week it was running, the next week it was catching, the next week it was passing, and so on.” Although the link between physical literacy and the enjoyment of physical activity was not made by participants in the focus groups, there was evidence that the program was fun and that the program made participants want to play more sports and be more active generally: "after the first time you tried it you want to do it every single day because it is so fun," and "I have always been quite a sporty person...but I think that the [league] program...helped children like me and a few of my classmates I know they definitely now want to play more sports and be much more active."

\subsubsection{Theme \#2 (physical activity): A position for everyone, in and out of school}

Significant increases in moderate and high intensity physical activity are by-products of increased access to physical activity. However, this was evident only in the administrator interviews and not the participant focus groups. The League's sport made it accessible to participants with different skills, which further enabled the mild physical activity outcomes. The program designer commented: "Not all children are good at kicking a ball, but we were able to capture more children by offering a greater variety of skills than would normally be taught as part of a PE curriculum.” A program coach also commented:

We actively made it accessible to all children, regardless of disability, gender, ability. Everyone took part. We had a boy with cerebral palsy, who loved to get involved. [Sport] is a sport for everyone. Everyone has a role. The children learnt to use each other's natural abilities. The children learnt to do this themselves. 
Only a ball is needed to play the sport used in the program, which made it accessible outside of PE classes. The program designer stated: "The program was set up to make sure that the kids could do all of the activities outside of school. [...] All you need is a ball.” Limited equipment made it possible to set homework of practicing The League's sport so to make physical activity more of a habit. The program coach identified that: "We set them homework to do outside of school [...] these were short exercises that they could do at any point. It was to get them to do it regularly, repetitively, so that it becomes a habit." Examples included sprints and vertical jumps.

\subsubsection{Theme \#3 (physical activity): How can we make you better?}

Increased levels of moderate and high intensity physical activity can be partially explained by the program's progressive physical activity curriculum, whereby drills became progressively more challenging as the program advanced. The coaches served as a source of motivation for participants by pushing participants to stretch their limits. One participant noted "I have never really tried to play [sport] but now that I have, I've tried to get faster." According to a program coach and a participant:

We set little challenges that they could achieve, but for which they needed to work to achieve. Nothing was ever easy, but that provided a sense of achievement. When they completed a deep pass for the first time, they were like 'Wow! Now how can we make that better?' There was always something to improve upon.

I thought that I was quite fit before it [the program], but now I know I need to keep on pushing myself because I got a bit tired whenever I was doing it [the program], but it's really made my activity levels go much higher than they used to be. 


\subsubsection{Theme \#4 (sport identification and physical activity): A novel sport identity}

The significant effect on sport affinity/identification stems from the development of a novel sport identity among participants. The choices that young people make about the physical activities they participate in relate to the way they view themselves and their relation to the social world (Coakley \& White, 1992). Within the UK, The League's sport is new compared to the mainstream sports of soccer and rugby. By engaging in the activity, participants were able to develop a novel sport identity, which may also serve as motivation for increased levels of participation and sport enjoyment (Epstein, 1998; Hughson et al., 2005). One coach commented: "Most kids like it because of the novelty of it." A participant observed: "When I think about [The League's sport] I enjoy it and it makes me happy because [The League's sport] is a sport not many people get to play so I enjoy getting to try new things" Another participant observed:

Cause I've known football [soccer] since I was a baby and been playing it for a long time I kind of got bored of it and [The League's sport] is new, it's fun, it's fresh, so I rather like to get on my feet and play [The League's sport] more now than football [soccer].

\subsubsection{Theme \#5 (mental wellness): Sport analogies}

While none the wellness variables were influenced through program participation, focus group participants suggested that they could recognize positive wellness in themselves and others. One participant noted: "I see the good things in people who are honest and help people." Another reflected: "I would never hurt a friend, and would always make sure they are not hurt by others." Terminology and analogies from the sport itself educated the participants about the wellness attributes on the basis that the sport represented a context 
whereby the inherent values were transferable to everyday life. According to the program designer:

There's no other sport that is so reliant upon teamwork and everyone having a role, and everyone doing their role in order for the team to have success. There are so many scenarios in the game that relates to real life, a struggle, and how you work to overcome obstacles. The physical aspects of [The League's sport] bring out the personal attributes, such as perseverance. The blood, sweat and tears is closer to real life than people realize.

The wellness curriculum made it real for the children. There were many scenarios that the children go through themselves on a daily basis. Because they could relate to these scenarios, they could understand how the character attribute played out in real life.

A program coach also identified how character attributes were taught in a classroom setting and practiced in the sport component of the program outside of class:

It's a case of living and practicing what you preach. The coaches tried to demonstrate the personal attributes in their behavior and also bring the attributes into the physical activity component, such as teaching how to show respect to an opponent after the game.

\subsubsection{Theme \#6 (mental wellness): Role models}

While the sport was seemingly a strong vehicle through which to develop mental wellness, The League players represented role models who the participants could idolize. For example, as described by the program coordinator: "[professional player] spent half a day with the school, in the auditorium with the entire school and faculty talking about his journey and what character attributes are important to get you to where you want to go." According to 
one teacher: "the children looked up to the [The League] players, so they took notice of what they had to say about character, maybe more so than they would if coming from their teachers." However, the head of delivery noted that participants did not explicitly identify with the former players as role models in the mental wellness curriculum: "The children could not identify with the [former players] as much as we would have wanted them to. The children did not know who they were. I believe current players would serve as better role models in the program." Furthermore, the risk of using role models as change agents is that they may behave in ways that are in conflict with the messages of a social intervention. While was not observed in the data, it provided an avenue for future program modification.

\subsubsection{Theme \#7 (team identification): Six teams for six schools}

A partial explanation for the significant effect of the program on team identifcation is through the involvement of League-affiliated teams. The teams discussed by the participants were almost exclusively teams that were part of this initiative, as opposed to the perhaps more high-profile teams, who have the largest fan bases in The League. Instead, participants expressed a liking for teams representing their particular school. Also, participants were able to better communicate facts about the game, which ranged from positions, to teams and roles of players. Six league teams each adopted one of the six schools participating in the program. This was done so that each school could develop a connection to that particular team that could be leveraged. The head of delivery described the end of program tournament:

We tied in our [end of program tournament] with the [league] media day, which brought each of the six participating schools into the media day. Each team sent over a player, who coached the teams in the tournament and gave character talks.

According to a program coach, a constant presence of teams in classrooms was achieved via apparel and merchandise: "we put team apparel into all of the classrooms. The [teams] sent over merchandise to give away to the children, whether that's caps, t-shirts, pencils, banners, 
posters, stickers, key rings." However, some teams engaged more than others, reflected in the differing levels of team affinity evident in the quantitative findings. As described by the program coordinator:

Every team interacted differently depending on their availability at that time. It was offseason, so availability was tough, but [player name] of the [team name] Skyped into the school and did a Q and A session with the children. The [school] participants also had Skype calls with a similar school in the City of [team city] as a cultural exchange. Ex-[team] player [player name] spent half a day at one school.

The program coordinator identified that one team was very engaged with their partner school, describing that "...the [team] arranged video calls with their mascot and their sports lab, so the children could see that it was a bigger thing than what they were just doing in the classroom or their school yard."

\subsubsection{Theme \#8 (league identification): Putting on a show}

The significant effect of the program on League and sport identification resulted from the use of League branding and imagery (i.e., coach kits, images, and videos), which served to enhance the vibrancy of the program. Moreover, the experiential nature of the program seemingly enabled the sport identification uptick in the data. As described by the head of delivery: "a lot of the pictures we used as examples of the correct technique were of [The League] players in training camps, in games. We used a lot of videos to demonstrate the movements." According to a teacher, The League brand made the program more attractive, who stated: "the [The League] excels at putting on a show. Going in without the [The League] brand, would have made the program very plain, very bland.”

\section{General discussion}

According to Porter and Kramer (2011), shared value "involves creating economic value in a way that also creates value for society by addressing its needs and challenges" ( $\mathrm{p}$. 
64). Thus, societal benefits and business benefits need not be mutually exclusive. The program examined herein provides evidence of mutually beneficial social and marketplace outcomes. The results show that increased physical activity as well as enjoyment and commitment to physical activity were programmatic outcomes. In addition, program engagement yielded business paybacks through enhanced sport, team, and League identification. Kramer and Porter (2011) identified three levels of shared value: (a) reconceiving products and markets (i.e., targeting organizational opportunities), (b) redefining productivity in the value chain (i.e., internal operations management), and (c) enabling cluster development (i.e., adapting to changing societal conditions). This program seemingly served The League's core business function of developing a fan base, but also created value for program beneficiaries through a physical (sport) activity curriculum.

By combining both business and social goals, a mutually supportive structure can extend beyond just achievement of business goals such as image enhancement, reputational solvency, and consumer purchase intent (Walker \& Kent, 2009; 2013). Additionally, professional sport organizations have a visible pulpit to aid in the promotion of health and wellness behaviors, since they are actors worthy of imitation and can inspire other people through interactions and relationships (Payne, Reynolds, Brown, \& Fleming, 2003). For the purpose of this study, we focus our attention on Kramer and Porter's (2011) first level of shared value - reconceiving products and markets - since the business-level outcomes of market expansion and improved profitability were drivers of the program. Although we did not specially measure enhanced profitability, nor did The League explicitly state that market penetration and profitability were the motives for program implementation, identification and behavioral intentions have revenue-generating potential for an organization. Intuitively, the League is attempting to penetrate a new market with a novel sport offering. From a businesslevel perspective, continued support of the program seems justified given the fandom-related 
benefits seen as a result or program engagement. The experiential nature of the sporting experience likely enabled the benefits, which is a positive sign in this particular market.

On the social side, programmatic features resulted in increased physical activity, enjoyment, and commitment to physical activity. These results support the potential of the program to result in societal outcomes, which strike a decent business/society balance. The business-centric did return the largest practical effects in the study. The latter focus is not necessarily a counterproductive approach to social responsibility; rather, it is an opportunity to leverage and reconceive the program around fandom to enable the health effects to materialize. In particular, we found significant effects on moderate- and high-intensity physical activity, physical activity enjoyment and commitment, and the affinity-related variables, all of which can be attributed to the intervention. However, the intervention did not produce a significant between-group effect on sedentary time, which served as an additional proxy measure of physical activity. While ideally, we would have liked to see increased physical activity coupled with a marked reduction in sedentary time, improved time spent in moderate and high physical activity is still notable. However, with only small effect sizes seen for physical activity, any impact on the beneficiates being more physically active is tenuous. However, we note a significant and large effect on physical activity enjoyment. This result suggest that increased physical activity in school yielded greater enjoyment in overall physical activity, which is critical to sustaining a behavior later in life and illustrates the effectiveness of using an experiential approach in a region where the sport is not widely played recreationally. The fact that these results materialized with limited program engagement speaks to the novelty of the sport intervention to yield physical activity enjoyment and improvements to physical inactivity, which were enhanced by the inclusive nature of the program. While these results correlate with the qualitative data, view them with caution since the program was temporally bracketed. 
Based on this commentary, it is reasonable to assume that increased program contact (i.e., hours per week and/or duration of program) could lead to a sustainable habit of being physically active. As noted in our introduction, delivery and deployment issues abound for social responsibility programs (Walker \& Hills, 2017). This program is certainly no different. At present, the idea of shared value espoused by Kramer and Porter (2011) is somewhat balanced across program outcomes. For example, the program was successful in marketing The League, the teams, and the sport (i.e., business outcomes), but impacts were small on physical activity levels. For greater sharing of value, the program deliverer should increase the time spent engaged in the activity and better integrate the curriculum with intentional design characteristics for mental wellness. For example, the mental wellness attributes should be contextually additive to school and parental support, rather than used as a classroom lesson. In addition, outside of school sport participation is necessary for prolonged engagement in the activity. Community hubs to promote grass roots recreational and structured play are needed.

The intervention had a significant and positive within-group influence on the identification variables, with relatively large effect sizes reported. As identification takes years to fully manifest (Wann, 2006) and is heavily contingent on repeated exposure and referent effects, this result was surprising. Team-related purchase intentions and positive advocacy can form as outcomes of identification, especially if the program continues and team branding and school engagement are cornerstones. At present, advocacy for the sport and will be limited among this group of participants. Despite this non-significant result, it seems that a bottom-up approach to fandom is being approached though the program. This approach has resulted in several layers of identification but given a short engagement time, yet did not influence patronage. 
This study adds to the expanding body of literature detailing the outcomes of health promotion programs in sport (Brady et al., 2010; Gray et al., 2013; Irwin et al., 2010; Pringle et al., 2013; Trigwell et al., 2015) and confirmed the limited net influence of social responsibility and on measurable health-related behaviors (Inoue et al., 2015). However, a difference with the program studied is that, even with small impacts on health promotion, due to considerable impact on business value, the program can overcome the short-term and funding issues suffered by many programs (Walker \& Hills, 2017). Considering the complex challenge of health promotion (Godin \& Kok, 1996; Baranowski et al., 2002; Johansen et al, 2016), expecting a program to have a considerable impact on all of the research variables related to health, wellness, and the business at the first attempt is certainly possible but the League should manager their expectations. Thus, by ensuring that a social program also provides business value, helps ensure that sport organization health promotion activities are sustainable. Moreover, linking core business objectives with a social programming approach will further aid in achieving certain outcomes. This synergistic approach connects a company's mission with social efforts to enhance competitiveness and simultaneously advance social conditions in communities where they operate. Rather than expecting sport organizations to act as charitable donors, which is not sustainable, they can act as businesses so that programs represent “... not philanthropy but self-interested behavior to create economic value by creating societal value” (Kramer \& Porter, 2011, p. 77).

\subsection{Practical implications}

We identified the potential of achieving business value and to a lesser extent health promotion, when shared value in social programming is pursued. Rather than designing interventions for purely health promotion or purely business value, practitioners should seek a balance of both. In this study, there was limited evidence of health benefits beyond the effects for enjoyment of and commitment to physical activity. However, the business value 
was slightly more conclusive and considerable. In our opinion, this is a stronger foundation from which to expand the program, since it offers the business a more justifiable means of growing the program. In a perfectly altruistic world, we would hope the pursuit of social value would be the ultimate goal. However, as Kramer and Porter (2011) remarked, this is a non-sustainable approach since social programs are expensive, time consuming, and often deviate from core business functions. As such, we advocate collaboration between marketing and development practitioners to ensure the program is achieving business but not lose the physical activity focus. Based on insights from the research, conversations with the program developers and implementers, and lessons learned from the collaborative experience, adjustments will better impact the health outcomes. For example, we suggested more emphasis on physical literacy and fundamental physical movements so enjoyment of sport and physical activity extend beyond the sport itself. It is important to bolster both business and social outcomes because if managers pursued business value alone, consumers (and program stakeholders) would likely become cynical (Wagner, Lutz, \& Weitz, 2009) and achieved business value lost.

The presence of The League was able to generate business value in the form of team, sport, and League identification. These results suggest that sport organizations can develop fandom with school programs without having to change the health-related markers embedded in the program structure. However, such an approach is short-sighted because, although the effect was non-existent for team and League patronage, participation had a large effect on identification, which provided a connection that could potentially sustain advocacy and patronage. As such, managers should not simply attempt to have a presence in schools to enable greater business value, they need to fully engage participants through branding communications to establish a connection and actually produce shared value. 


\subsection{Limitations and future research}

It is reasonable to assume that greater impact on character development and physical should result from additional contact time spent on the messaging and activities, which could be achieved via increasing the program duration and wider incorporation of character education and physical activity messaging. In order to counter the spillover effects, a fully randomized trial would provide the opportunity to draw conclusions most confidently, which was not possible in this case as non-participating schools were unwilling to provide researchers access. Failure to interview senior managers who ultimately determined future funding of the program was also a limitation of this study. These managers were not based in the UK, which made access difficult but not impossible. Future research could include their perspective so to better understand the concept of shared value from a more senior and nonlocal level in The League.

To overcome the limitation of small effects on physical activity, future researchers should take a more nuanced approach to the measurement of physical activity, which is a multi-faceted idea. Consequently, researchers have noted that investigators should combine multiple physical activity assessments for enhanced design robustness (Sylvia et al., 2014). While assessing both sedentary activity and intentional engagement in activity was a strength of this project, both are subject to the biases associated with self-report data. Use of accelerometers, pedometers, or heart rate monitors would serve as a complimentary component to self-report data in future investigations. For example, it is important for researchers to understand the strengths and weaknesses of each modality prior to determine the best data collection method for their specific sample (Sylvia et al., 2014). Future researchers could also collect longitudinal data to determine if changes were temporal or sustained. Tracking of the status of program continuation in relation to the social and 
business value it achieves, could offer some insight into the importance of pursuing shared value.

If longitudinal research is conducted, the health benefits that are linked to increased levels of physical activity should be measured (e.g., pre- and post-Body Mass Index, BMI, measurements) to provide a stronger theoretical framework that establishes both intermediate impacts (i.e., physically active) and broader outcomes (i.e., improve health and quality of life). Yet, pinning programmatic success and/or failure to outcomes, such as BMI, has the potential to be misleading. Specifically, scholars have outlined how surrogate anthropometric measures, such as BMI, may provide misleading body fat content information (Prentice \& Jebb, 2001). For instance, BMI measures do not "distinguish fat from fat-free mass such as muscle and bone" (Burkhauser \& Cawley, 2008, p. 519). Thus, as in the case of selecting physical activity measures, thought should go into how best to capture improvement to body composition and health overall. For this evaluation, this was not possible. The schools were reticent to allow this since we were outside research consultants with no training or ability to provide a health screening. Additionally, there would have been multiple school board and student protection issues in the UK to overcome. 


\section{References}

Babiak, K., \& Wolfe, R. (2009). Determinants of corporate social responsibility in professional sport: Internal and external factors. Journal of Sport Management, 23(6), 717-742.

Bailey, R., Hillman, C., Arent, S., \& Petitpas, A. (2013). Physical activity: an underestimated investment in human capital. Journal of Physical Activity and Health, 10(3), 289-308.

Baranowski, T., Perry, C. L., \& Parcel, G. S. (2002). How individuals, environments, and health behavior interact. Health behavior and health education: Theory, research, and practice, 3, 165-184.

Beschorner, T. (2014). Creating shared value: The one-trick pony approach. Business Ethics Journal Review, 1(17), 106-112.

Brady, A., Perry, C., Murdoch, D., \& McKay, G. (2010). Sustained benefits of a health project for middle-aged supporters at Glasgow Celtic and Rangers football clubs. European Heart Journal, 31(24), 2696-2698.

British Heart Foundation (2015). Physical Activity Statistics 2015. Retrieved 25 August 2015, from https://www.bhf.org.uk/ /media/files/publications/research/bhf_physicalactivity-statistics-2015feb.pdf

Burkhauser, R. V., \& Cawley, J. (2008). Beyond BMI: the value of more accurate measures of fatness and obesity in social science research. Journal of Health Economics, 27(2), 519-529.

Coakley, J., \& White, A. (1992). Making decisions: Gender and sport participation among British adolescents. Sociology of Sport Journal, 9(1), 20-35.

Cohen, J. (1992). A power primer. Psychological Bulletin, 112(1), 155.

Corder, K., Ekelund, U., Steele, R. M., Wareham, N. J., \& Brage, S. (2008). Assessment of physical activity in youth. Journal of Applied Physiology, 105(3), 977-987.

Cordray, D. S. (1986). Quasi-experimental analysis: A mixture of methods and judgment. New Directions for Evaluation, 1986(31), 9-27.

Creswell, J. (2012). Research design: Qualitative, Quantitative, and Mixed Methods Approaches. Thousand Oaks, California: Sage Publications.

Creswell, J. W., \& Miller, D. L. (2000). Determining validity in qualitative inquiry. Theory into practice, 39(3), 124-130.

Cui, Y., Guo, J., Santiago-Torres, M., Schoeller, D., Esmond, S., Allen, D., \& Carrel, A. (2015). Assessing children's time-use in relation to physical fitness and risks of obesity and diabetes: Development of a new physical activity self-report instrument. BAOJ Obesity \& Weight Loss Management, 1(1), 1-18.

Curran, P. J., West, S. G., \& Finch, J. F. (1996). The robustness of test statistics to nonnormality and specification error in confirmatory factor analysis. Psychological Methods, 1(1), 16.

Denzin, N. K., \& Lincoln, Y. S. (2011). The Sage handbook of qualitative research. Thousand Oaks, California: Sage Publications.

Dimmock, J. A., \& Grove, J. R. (2006). Identification with sport team as a function of the search for certainty. Journal of Sport Sciences, 24(11), 1203-1211.

Du, S., Bhattacharya, C. B., \& Sen, S. (2010). Maximizing business returns to corporate social responsibility (SOCIAL RESPONSIBILITY): The role of SOCIAL RESPONSIBILITY communication. International Journal of Management Reviews, 12(1), 8-19.

Duckworth, A. L., Peterson, C., Matthews, M. D., \& Kelly, D. R. (2007). Grit: Perseverance and passion for long-term goals. Journal of Personality and Social Psychology, 92(6), 1087-1099. 
Driver, M. (2012). An interview with Michael Porter: Social entrepreneurship and the transformation of capitalism. Academy of Management Learning \& Education, 11(3), 421-431.

Ellen, P. S., Webb, D. J., \& Mohr, L. A. (2006). Building corporate associations: Consumer attributions for corporate socially responsible programs. Journal of the Academy of Marketing Science, 34(2), 147-157.

Epstein, J. (Ed.). (1998). Youth culture: Identity in a postmodern world. Hoboken, NJ: Blackwell Publishing.

Firestone, W. A. (1993). Alternative arguments for generalizing from data as applied to qualitative research. Educational Researcher, 22(4), 16-23.

Funk, D. C., \& James, J. (2001). The psychological continuum model: A conceptual framework for understanding an individual's psychological connection to sport. Sport Management Review, 4(2), 119-150.

Gillham, J., Adams-Deutsch, Z., Werner, J., Reivich, K., Coulter-Heindl, V., Linkins, M., Winder, B., Peterson, C., Park, N., Abenavoil, R., Contero, A., \& Seligman, M. E. (2011). Character strengths predict subjective well-being during adolescence. The Journal of Positive Psychology, 6(1), 31-44.

Godfrey, P. C. (2009). Corporate social responsibility in sport: An overview and key issues. Journal of Sport Management, 23(6), 698-716.

Godin, G., \& Kok, G. (1996). The theory of planned behavior: a review of its applications to health-related behaviors. American Journal of Health Promotion, 11(2), 87-98.

Gray, C. M., Hunt, K., Mutrie, N., Anderson, A. S., Leishman, J., \& Dalgamo, L. (2013). Football fans in training: the development and optimization of an intervention delivered through professional sports clubs to help men lose weight, become more active and adopt healthier eating habits. BMC Public Health, 13, 232-256.

Green, K. (2004). Physical education, lifelong participation and 'the couch potato society'. Physical Education \& Sport Pedagogy, 9(1), 73-86.

Grøntved, A., Ried-Larsen, M., Møller, N. C., Kristensen, P. L., Wedderkopp, N., Froberg, K., \& Andersen, L. B. (2014). Youth screen-time behaviour is associated with cardiovascular risk in young adulthood: the European Youth Heart Study. European journal of preventive cardiology, 21(1), 49-56.

Hakim, C. (2000). Research design: Successful designs for social and economic research. London, UK: Psychology Press.

Hamilton, M. T., Healy, G. N., Dunstan, D. W., Zderic, T. W., \& Owen, N. (2008). Too little exercise and too much sitting: inactivity physiology and the need for new recommendations on sedentary behavior. Current Cardiovascular Risk Reports, 2(4), 292-298.

Hart, S. L. (2005).Capitalism at the crossroads: The unlimited business opportunities in solving the world's most difficult problems. Upper Saddle River, NJ: Wharton School.

Heere, B., \& James, J. D. (2007). Sports teams and their communities: Examining the influence of external group identities on team identity. Journal of Sport Management, 21(3), 319-337.

Hills, L. (2007). Friendship, physicality, and physical education: an exploration of the social and embodied dynamics of girls' physical education experiences. Sport, Education and Eociety, 12(3), 317-336.

Hughson, J., Inglis, D., \& Free, M. W. (2005). The uses of sport. London: Routledge.

Inoue, Y., \& Kent, A. (2012). Investigating the role of corporate credibility in corporate social marketing: A case study of environmental initiatives by professional sport organizations. Sport Management Review, 15(3), 330-344. 
Inoue, Y., \& Kent, A. (2014). A conceptual framework for understanding the effects of corporate social marketing on consumer behavior. Journal of Business Ethics, 121(4), 621-633.

Inoue, Y., Kent, A., \& Lee, S. (2011). SOCIAL RESPONSIBILITY and the bottom line: Analyzing the link between SOCIAL RESPONSIBILITY and financial performance for professional teams. Journal of Sport Management, 25(6), 531-549.

Inoue, Y., Yli-Piipari, S., Layne, T., Chambliss, H. O., \& Irwin, C. C. (2015). A preliminary study of a professional sport organization's family-centered health promotion initiative. International Review on Public and Nonprofit Marketing, 12(2), 189-205.

Irwin, C. C., Irwin, R. L., Miller, M. E., Somes, G. W., \& Richey, P. A. (2010). Get fit with the grizzlies: A community-school-home initiative to fight childhood obesity. Journal of School Health, 80(7), 333-339.

Irwin, R. L., Lachowetz, T., \& Clark, J. (2010). Cause-related sport marketing: Can this marketing strategy affect company decision-makers?. Journal of Management \& Organization, 16(4), 550-556.

Ivankova, N. V., Creswell, J. W., \& Stick, S. L. (2006). Using mixed-methods sequential explanatory design: From theory to practice. Field Methods, 18(1), 3-20.

James, J. D. (2001). The role of cognitive development and socialization in the initial development of team loyalty. Leisure Sciences, 23(4), 233-261.

Johansen, A., Rasmussen, S., \& Madsen, M. (2006). Health behaviour among adolescents in Denmark: influence of school class and individual risk factors. Scandinavian Journal of Social Medicine, 34(1), 32-40.

Johnson, R. B., \& Onwuegbuzie, A. J. (2004). Mixed methods research: A research paradigm whose time has come. Educational researcher, 33(7), 14-26.

Johnson, B., \& Turner, L. A. (2003). Data collection strategies in mixed methods research. In Tashakkori, A \& Teddlie, C. (Ed.), Handbook of mixed methods in social and behavioral research (297-319). Thousand Oaks, California: Sage Publications.

Khan, K. M., Thompson, A. M., Blair, S. N., Sallis, J. F., Powell, K. E., Bull, F. C., \& Bauman, A. E. (2012). Sport and exercise as contributors to the health of nations. The Lancet, 380(9836), 59-64.

King's College London (2015). A third of children in England are overweight/obese. Retrieved 25 August, from http://www.kcl.ac.uk/newsevents/news/newsrecords/2015/January/A-third-ofchildren-in-England-are-overweightobese.aspx

Kim, K. T., Kwak, D. H., \& Kim, Y. K. (2010). The impact of cause-related marketing (CRM) in spectator sport. Journal of Management \& Organization, 16(4), 515-527.

Kowalski, K. C., Crocker, P. R., \& Donen, R. M. (2004). The physical activity questionnaire for older children (PAQ-C) and adolescents (PAQ-A) manual. College of Kinesiology, University of Saskatchewan, 87(1), 1-38.

Kramer, M. R., \& Porter, M. (2011). Creating shared value. Harvard Business Review, 89(1/2), 62-77.

MacArthur, G. J., Smith, M. C., Melotti, R., Heron, J., Macleod, J., Hickman, M., ... \& Lewis, G. (2012). Patterns of alcohol use and multiple risk behaviour by gender during early and late adolescence: the ALSPAC cohort. Journal of Public Health, 34(suppl_1), i20-i30.

Maxwell, J. A. (2012). Qualitative research design: An interactive approach (Vol. 41). Thousand Oaks, California: Sage publications.

Mayo Clinic (2017). Exercise intensity: How to measure it. Retrieved 1 August, from http://www.mayoclinic.org/healthy-lifestyle/fitness/in-depth/exercise-intensity/art20046887 
McCrorie, P. R. W., Perez, A., \& Ellaway, A. (2017). The validity of the Youth Physical Activity Questionnaire in 12-13-year-old Scottish adolescents. BMJ Open Sport \& Exercise Medicine, 2(1), e000163.

McElhaney, K. (2007). Strategic SOCIAL RESPONSIBILITY. Sustainable Enterprise Quarterly, 4(1), 1-7.

McWilliams, A., \& Siegel, D. S. (2011). Creating and capturing value: Strategic corporate social responsibility, resource-based theory, and sustainable competitive advantage. Journal of Management, 37(5), 1480-1495.

Micheli, L., Mountjoy, M., Engebretsen, L., Hardman, K., Kahlmeier, S., Lambert, E., \& Sundberg, C. J. (2011). Fitness and health of children through sport: the context for action. British Journal of Sports Medicine, 45(11), 931-936.

Miller, D. N., Gilman, R., \& Martens, M. P. (2008). Wellness promotion in the schools: Enhancing students' mental and physical health. Psychology in the Schools, 45(1), 515.

Moore, J. B., Yin, Z., Hanes, J., Duda, J., Gutin, B., \& Barbeau, P. (2009). Measuring enjoyment of physical activity in children: Validation of the physical activity enjoyment scale. Journal of Applied Sport Psychology, 21(S1), 116-129.

Morgan, D. L. (1996). Focus groups. Annual review of sociology, 22(1), 129-152.

National Statistics (2017). Statistics on Obesity, Physical Activity and Diet England: 2017. Retrieved 19 March 2018, from https://www.gov.uk/government/uploads/system/uploads/attachment_data/file/613532 /obes-phys-acti-diet-eng-2017-rep.pdf

Ng, S. W., \& Popkin, B. M. (2012). Time use and physical activity: a shift away from movement across the globe. Obesity Reviews, 13(8), 659-680.

Noble, B. J., Borg, G. A., Jacobs, I. R. A., Ceci, R., \& Kaiser, P. (1983). A category-ratio perceived exertion scale: relationship to blood and muscle lactates and heart rate. Medicine and Science in Sports and Exercise, 15(6), 523-528.

Okely, A.D., Booth, M.L., \& Patterson, J.W. (2001). Relationship of physical activity to fundamental movement skills among adolescents. Medicine and Science in Sports and Exercise, 33(11), 1899-1904.

Owen, N., Sparling, P. B., Healy, G. N., Dunstan, D. W., \& Matthews, C. E. (2010a). Sedentary behavior: emerging evidence for a new health risk. In Mayo Clinic Proceedings (Vol. 85, No. 12, pp. 1138-1141).

Owen, N., Healy, G. N., Matthews, C. E., \& Dunstan, D. W. (2010b). Too much sitting: the population-health science of sedentary behavior. Exercise and Sport Sciences Reviews, 38(3), 105.

Park, N., \& Peterson, C. (2006). Moral competence and character strengths among adolescents: The development and validation of the Values in Action Inventory of Strengths for Youth. Journal of Adolescence, 29(6), 891-909.

Park, N., \& Peterson, C. (2006). Moral competence and character strengths among adolescents: The development and validation of the Values in Action Inventory of Strengths for Youth. Journal of Adolescence, 29(6), 891-909.

Paton, G. (2013). Lessons in 'character' should be placed on curriculum. Telegraph.co.uk. Retrieved 25 August, from http://www.telegraph.co.uk/education/educationnews/10350421/Lessons-in-charactershould-be-placed-on-curriculum.html

Pavlovich, K., \& Corner, P. D. (2014). Conscious enterprise emergence: Shared value creation through expanded conscious awareness. Journal of Business Ethics, 121(3), 341-351. 
Payne, W., Reynolds, M., Brown, S., \& Fleming, A. (2003). Sports role models and their impact on participation in physical activity: a literature review. Victoria: VicHealth, 74.

Peterson, C. (2006). A primer in positive psychology. New York: Oxford University Press.

Porter, M. E., \& Kramer, M. R. (2011). The big idea: Creating shared value. How to reinvent capitalism - and unleash a wave of innovation and growth. Harvard Business Review, 89(1-2).

Prentice, A. M., \& Jebb, S. A. (2001). Beyond body mass index. Obesity Reviews, 2(3), 141147.

Pringle, A., Zwolinsky, S., McKenna, J., Daly-Smith, A., Robertson, S., \& White, A. (2013). Effect of a national programme of men's health delivered in English Premier League football clubs. Public Health, 127(1), 18-26.

Robertson, S, Zwolinsky, S., Pringle, A., McKenna, J., Daly-Smith, A., \& White, A (2013) 'It is fun, fitness and football really': a process evaluation of a football-based health intervention for men. Qualitative Research in Sport, Exercise and Health, 5(3), 419439,

Scanlan, T. K., Simons, J. P., Carpenter, P. J., Schmidt, G. W., \& Keeler, B. (1993). The Sport Commitment Model: Measurement development for the youth-sport domain. Journal of Sport \& Exercise Psychology, 15(1).

Sefton, T., Byford, S., McDaid, D., Hills, J., \& Knapp, M. (2002). Making the most of it. Economic evaluation in the social welfare field. York: Joseph Rowntree Foundation.

Shephard, R. J. (2003). Limits to the measurement of habitual physical activity by questionnaires. British Journal of Sports Medicine, 37(3), 197-206.

Siegel, D. S., \& Vitaliano, D. F. (2007). An empirical analysis of the strategic use of corporate social responsibility. Journal of Economics \& Management Strategy, 16(3), 773-792.

Snyder, F., Flay, B., Vuchinich, S., Acock, A., Washburn, I., Beets, M., \& Li, K. K. (2009). Impact of a social-emotional and character development program on school-level indicators of academic achievement, absenteeism, and disciplinary outcomes: A matched-pair, cluster-randomized, comparisonled trial. Journal of Research on Educational Effectiveness, 3(1), 26-55.

Spiggle, S. (1994). Analysis and interpretation of qualitative data in consumer research. Journal of Consumer Research, 21(3), 491-503.

Stevenson, B. (2010). Beyond the classroom: Using Title IX to measure the return to high school sports. Review of Economics and Statistics, 92, 284-301,

Strauss, A., \& Corbin, J. (1998). Basics of qualitative research techniques. Thousand Oaks, California: Sage publications.

Sylvia, L. G., Bernstein, E. E., Hubbard, J. L., Keating, L., \& Anderson, E. J. (2014). Practical guide to measuring physical activity. Journal of the Academy of Nutrition and Dietetics, 114(2), 199-208.

Trust for London and New Policy Institute (2013). London's Poverty Profile. Retrieved 25 August, from http://www.londonspovertyprofile.org.uk/key-facts/overview- oflondon-boroughs/

Tudor-Locke, C. E., \& Myers, A. M. (2001). Methodological considerations for researchers and practitioners using pedometers to measure physical (ambulatory) activity. Research Quarterly for Exercise and Sport, 72(1), 1-12.

Trigwell, J., Murphy, R. C., Cable, N. T., Stratton, G., \& Watson, P. M. (2015). Parental views of children's physical activity: a qualitative study with parents from multiethnic backgrounds living in England. BMC Public Health, 15(1), 1005. 
Van Quaquebeke, N., \& Eckloff, T. (2010). Defining respectful leadership: What it is, how it can be measured, and another glimpse at what it is related to. Journal of Business Ethics, 91(3), 343-358.

Wagner, T., Lutz, R. J., \& Weitz, B. A. (2009). Corporate hypocrisy: Overcoming the threat of inconsistent corporate social responsibility perceptions. Journal of Marketing, 73(6), 77-91.

Walker, M., Heere, B., Parent, M. M., \& Drane, D. (2010). Social responsibility and the Olympic Games: The mediating role of consumer attributions. Journal of Business Ethics, 95(4), 659-680.

Walker, M., \& Hills, S. (2017). Social Program Evaluations: Strategies and Shared Value. Sport \& Entertainment Review,(3)3, 65-71.

Walker, M., \& Kent, A. (2009). Do fans care? Assessing the influence of corporate social responsibility on consumer attitudes in the sport industry. Journal of Sport Management, 23(6), 743-769.

Walker, M., \& Kent, A. (2013). The roles of credibility and social consciousness in the corporate philanthropy-consumer behavior relationship. Journal of Business Ethics, 116(2), 341-353.

Walker, M., Hills, S., \& Heere, B. (2017). Evaluating a socially responsible employment program: Beneficiary impacts and stakeholder perceptions. Journal of Business Ethics, 143(1), 53-70.

Walker, M., \& Mercado, H. (2016). Environmentally responsible value orientations: perspectives from public assembly facility managers. Corporate Social responsibility and Environmental Management, 23(5), 271-282.

Walters, G., \& Tacon, R. (2010). Corporate social responsibility in sport: Stakeholder management in the UK football industry. Journal of Management \& Organization, $16(4), 566-586$.

Wann, D. L. (2006). The causes and consequences of sport team identification. Handbook of Sports and Media, 331-352.

Whitehead, M. (2013). What is physical literacy and how does it impact on physical education. Debates in Physical Education, 37-52.

World Health Organization (1986). Ottawa Charter for Health Promotion: First international Conference on Health Promotion Retrieved April 1 from: http://www.who.int/hpr/NPH/docs/ottawa_charter_hp.pdf. 
Table 1. Constructs and Example Items

\begin{tabular}{|c|c|}
\hline Variable & Example Items \\
\hline Physical Activity & $\begin{array}{l}\text { In the last } 7 \text { days, on how many days did you do physical activities that caused you to } \\
\text { be out of breath (made it difficult to talk)? }\end{array}$ \\
\hline Sedentary Time & $\begin{array}{l}\text { In the last } 7 \text { days, on how many days did you watch/stream TV shows, movies, etc. on } \\
\text { your television, PC, or tablet? }\end{array}$ \\
\hline Physical Activity Enjoyment ${ }^{\text {a }}$ & $\begin{array}{l}\text { [When playing a sport or being physically active how often do you] ... enjoy it } \\
{[\text { When playing a sport or being physically active how often do you] ... feel happy }}\end{array}$ \\
\hline Physical Activity Commitment ${ }^{b}$ & $\begin{array}{l}\text { I am dedicated to being physically active } \\
\text { I will stay being physically active }\end{array}$ \\
\hline Respectfulness $^{\mathrm{b}}$ & $\begin{array}{l}\text { I am friendly towards other people } \\
\text { I treat other people as I would like to be treated }\end{array}$ \\
\hline Teamwork $^{b}$ & $\begin{array}{l}\text { I am a very loyal member of my team } \\
\text { In a team I give everyone an equal chance to be involved }\end{array}$ \\
\hline Integrity $^{b}$ & $\begin{array}{l}\text { I am less than honest if it will keep me out of trouble (R) } \\
\text { I tell the truth even when it means I won't get what I want }\end{array}$ \\
\hline Perseverance $^{\mathrm{b}}$ & $\begin{array}{l}\text { When I face challenges, I overcome them } \\
\text { I give up if something gets too hard }(\mathrm{R})\end{array}$ \\
\hline Team Affinity ${ }^{\mathrm{d}}$ & $\begin{array}{l}\text { My classmates like the }[\text { team }] \\
\text { I am proud to be a fan of the }[\text { team }]\end{array}$ \\
\hline Sport Affinity ${ }^{\mathrm{d}}$ & $\begin{array}{l}\text { My classmates like to play [sport }] \\
\text { I am proud to be a [sport }] \text { player }\end{array}$ \\
\hline League Affinity ${ }^{\mathrm{d}}$ & $\begin{array}{l}\text { My classmates like the [league] } \\
\text { I am proud to be a fan of the [league] }\end{array}$ \\
\hline Team Advocate ${ }^{a}$ & $\begin{array}{l}{[\text { How often do you }] \ldots \text { speak highly of }[\text { team }] \text { to your friends? }} \\
{[\text { How often do you }] \ldots \text { encourage your friends to support }[\text { team }] \text { ? }}\end{array}$ \\
\hline Team Patronage $^{a}$ & $\begin{array}{l}{[\text { How often do you }] \ldots \text { read about }[\text { team }] \text { on social media? }} \\
{[\text { How often do you }] . . \text { look up information on }[\text { team }] ?}\end{array}$ \\
\hline League Advocate $^{\text {a }}$ & $\begin{array}{l}[\text { How often do you }] \ldots \text { speak highly of [league }] \text { to your friends } \\
[\text { How often do you }] . . \text { encourage your friends to support [league }]\end{array}$ \\
\hline League Patronage $^{\text {a }}$ & $\begin{array}{l}{[\text { How often do you }] \ldots \text { read about }[\text { league }] \text { on social media? }} \\
{[\text { How often do you }] \text {... look up information on }[\text { league }] ?}\end{array}$ \\
\hline Sport Participation ${ }^{\text {a }}$ & $\begin{array}{l}{[\text { How often do you }] \text {... play }[\text { sport }] \text { as a game on your computer, console or phone? }} \\
{[\text { How often do you }] \text {... choose to play }[\text { sport }] \text { when you can choose to play any sport? }}\end{array}$ \\
\hline
\end{tabular}

Note. a Anchored by a 5-point scale from 1 "Never" to 5 "Always"

b Anchored by a 5-point scale from 1 "Not at all like me" to 5 "Very much like me"

c Anchored by a 5-point scale from 1 "Very difficult" to 5 "Very easy"

dAnchored by a 5-point scale from 1 "Very false" to 5 "Very true" 
Table 2. Treatment and Comparison Group Descriptive Statistics

\begin{tabular}{|c|c|c|c|c|}
\hline & $\begin{array}{c}\text { Pre-Program } \\
\text { (treatment) }\end{array}$ & $\begin{array}{l}\text { Post-Program } \\
\text { (treatment) }\end{array}$ & $\begin{array}{l}\text { Pre-Program } \\
\text { (comparison) }\end{array}$ & $\begin{array}{c}\text { Post-Program } \\
\text { (comparison) }\end{array}$ \\
\hline Constructs & $\operatorname{Mean}(S D)$ & $\operatorname{Mean}(S D)$ & $\operatorname{Mean}(S D)$ & $\operatorname{Mean}(S D)$ \\
\hline Vigorous Intensity PA ${ }^{a}$ & $501.04(616.50)$ & $1513.54(5408.18)$ & $342.87(721.40)$ & $837.80(4325.21)$ \\
\hline Moderate Intensity PA ${ }^{a}$ & $357.19(480.02)$ & 904.15 (2809.76) & $281.35(686.88)$ & $106.50(186.30)$ \\
\hline Low Intensity $\mathrm{PA}^{\mathrm{a}}$ & $341.24(512.96)$ & $630.69(2211.31)$ & $279.37(494.05)$ & $548.06(321.03)$ \\
\hline Watching TV a, b & $750.60(766.15)$ & $1379.66(3001.06)$ & $1471.71(1655.21)$ & $788.19(1680.80)$ \\
\hline Internet $\mathrm{a}, \mathrm{b}$ & $480.04(599.91)$ & $1049.90(3846.37)$ & $469.38(781.71)$ & $285.25(382.34)$ \\
\hline Computers ${ }^{\mathrm{a}, \mathrm{b}}$ & $595.82(671.90)$ & $1314.65(3794.62)$ & $910.13(1314.96)$ & $345.04(594.81)$ \\
\hline Physical Activity Enjoyment & $3.77(1.05)$ & $4.49(.631)$ & $4.57(.595)$ & $4.31(.650)$ \\
\hline Physical Activity Commitment & $3.84(1.01)$ & $4.13(.878)$ & $4.11(.766)$ & $4.37(.691)$ \\
\hline Respect $^{\mathrm{b}}$ & $4.48(.714)$ & $4.46(.670)$ & $4.19(.852)$ & $4.36(.696)$ \\
\hline Teamwork ${ }^{b}$ & $4.48(.581)$ & $4.38(.626)$ & $4.40(.598)$ & $4.30(.790)$ \\
\hline Integrity ${ }^{b}$ & $4.05(1.32)$ & $4.12(.754)$ & $3.97(.675)$ & $4.08(.746)$ \\
\hline Perseverance $^{b}$ & $3.73(.567)$ & $3.76(.529)$ & $3.81(.535)$ & $3.70(.616)$ \\
\hline Team Identification & $3.43(1.59)$ & $4.48(.701)$ & $3.56(2.97)$ & $3.78(.775)$ \\
\hline Sport Identification & $3.52(1.15)$ & $4.47(.698)$ & $3.78(.775)$ & $4.00(.850)$ \\
\hline League Identification & $3.68(1.35)$ & $4.52(.693)$ & $3.61(.914)$ & $3.86(1.10)$ \\
\hline Team Advocacy & $1.64(1.25)$ & $2.81(1.17)$ & $1.21(.587)$ & $2.83(1.46)$ \\
\hline League Advocacy & $1.84(1.17)$ & $2.94(1.24)$ & $1.79(1.16)$ & $2.73(1.55)$ \\
\hline Team Patronage & $1.52(.946)$ & $2.31(1.21)$ & $1.49(.926)$ & $2.19(1.42)$ \\
\hline League Patronage & $1.69(1.04)$ & $2.35(1.23)$ & $1.51(.813)$ & $2.49(1.35)$ \\
\hline Sport Participation & $2.04(1.09)$ & $2.78(1.17)$ & $2.31(1.12)$ & $2.56(1.42)$ \\
\hline
\end{tabular}

Note. ${ }^{\text {a }}$ Mean scores in minutes

${ }^{\mathrm{b}}$ Sedentary time was aggregated for all subsequent analyses 
Table 3. Repeated Measures ANOVA

\begin{tabular}{lccc}
\hline \hline Between-subjects effects & $\boldsymbol{F}$ Value $(\boldsymbol{d} f)$ & $\boldsymbol{p}$ Value & $\boldsymbol{d}$ \\
\hline Vigorous Intensity PA & $6.78(5)$ & .01 & .24 \\
Moderate Intensity PA & $5.54(5)$ & .02 & .25 \\
Low Intensity PA & $.682(5)$ & .43 & -- \\
Sedentary Time a & $.946(1)$ & .33 & - \\
Physical Activity Enjoyment & $7.89(1)$ & .01 & .80 \\
Physical Activity Commitment & $4.78(1)$ & .03 & .30 \\
Mental Wellness a & $1.20(1)$ & .27 & -- \\
Team Identification & $3.96(5)$ & .01 & .85 \\
Sport Identification & $4.01(5)$ & .00 & .99 \\
League Identification & $3.86(5)$ & .00 & .78 \\
Team Advocacy & $2.83(3)$ & .91 & -- \\
League Advocacy & $2.73(3)$ & .31 & -- \\
Team Patronage & $1.49(1)$ & .56 & -- \\
League Patronage & $2.49(1)$ & .51 & - \\
Sport Participation & 64.61 & & .60 \\
\hline
\end{tabular}

